\title{
Geology of Shantipur-Wami Taksar Areas of Gulmi-Baglung Dis- tricts, Western Nepal
}

\author{
Sushant Sapkota*, Pashupati Gaire and Kabi Raj Paudyal \\ Central Department of Geology, Tribhuwan University, Kritipur, Kathmandu,Nepal
}

\begin{abstract}
The study area represents a small part of the Lesser Himalaya in western Nepal and lies about $346 \mathrm{~km}$ west from Kathmandu. It covers $250 \mathrm{~km}$ area representing some parts of Gulmi and Baglung districts. The area was selected for the present study on the impression from the previous geological map that has showed some metallic mineral resources like iron, copper and lead in the region. Similarly, studies reveal that there is very complicated geological structure which raised the interest for the study. Main objective of the study was to prepare a geological map of the area in a scale of 1:25,000 and study the possible mineral deposits. An extensive geological mapping was carried out in the field covering at one data within one centimetre of the map scale and large number of samples was collected for the petrographic as well as ore genesis studies. The rocks of the region were mapped under two geological units as the Nourpul Formation (older) and the Dhading Dolomite (younger). There are a series of folds in the area. From regional to micro-scale all folds are trending towards east-west. The Badi Gad Fault and the Harewa Khola Thrust are the regional scale thrust mapped in the area. The Badi Gad is considered as a strike-slip in nature. The Harewa Khola Thrust is probably an imbricate fault. It has propagated to the north which is out of sequence in nature.
\end{abstract}

Some metallic minerals like copper and iron along with old working mines were observed during the study. Occurrences of copper and iron mineralization has been mapped and described. Present study revealed that copper mineralization is limited within the veins and boudinage forms as hydrothermal deposit while the iron is tabular and syngenetic in nature.

Key words: Badi Gad Fault, back thrust, copper and iron mineralization

Received: 8 March 2020

Accepted: 22 October 2020

\section{INTRODUCTION}

The study area represents a small part of the Lesser Himalaya in western Nepal and lies about $346 \mathrm{~km}$ west from Kathmandu. It covers $250 \mathrm{~km}$ area representing some parts of Gulmi and Baglung Districts.The study area lies in $27^{\circ} 12^{\prime} 30^{\prime \prime}$ to $28^{\circ} 05^{\prime} 00^{\prime \prime}$ north of latitude and $83^{\circ} 17^{\prime} 30^{\prime \prime}$ to $83^{\circ} 25^{\prime} 00^{\prime \prime}$ east of longitude. The geological study comprises the area between Shantipur-Wami Taksar in the Gulmi and Baglung Districts. Regional and few area-specific geological studies has been carried out by many scientists such asStöcklin and Bhattarai (1977) and Stöcklin (1980); DMG (2000); Sakai (1985); Dhital et al. (2002); Paudyal(2014).The map prepared by the DMG(2000) shows the very complicated structures, e.g. there are several vertical faults, which has a truncated the thick unit of the Nourpul Formation suddenly in the region making unusual geological structure which lead my curiosity to study in the area to map such a complicated structure. A geological map at a scale of 1:25,000 was prepared,occurrences of the potential minerals were identified and the geological control of mineralization of the area were also studied. This paper presents the result of geological mapping and mineral resources.

\section{METHODOLOGY}

The methodology adopted during the study can be broadly divided into four parts as: desk study, field work, laboratory

\section{${ }^{\star}$ Corresponding author}

Email: isushantspk@gmail.com work and data processing, interpretation and write up. In desk study, literatures like topographic maps, aerial photographs, and published papers were thoroughly reviewed. In field work, primary geological data were collected especially focusing on the preparation of geological maps and cross-section. Geological mapping was carried out with the help of Brunton compass, a tape, a hammer and a topographic map. Geological traverse was carried out along rivers, streams, ridges and all possible foot trails. The names of the stratigraphic units are adopted from the central Nepal Lesser Himalaya Stöcklin and Bhattarai (1977), Paudyal (2014). Geological map of the study area was prepared in a group where the first author worked as student and second author has the role of supervisor. Geological maps, longitudinal profiles, cross- sections and slope maps were prepared using the software like Geographic Information System (GIS), Coral Draw, Macromedia Freehand and Adobe Photoshop.Finally, all these data were compiled from field work and analysed for the interpretation.

\section{LITHOSTRATIGRAPHY}

The rocks of the study area are similar with the Nawakot Group of the Lesser Himalaya in the central Nepal. All the formations exposed in the central Nepal are not exposed in the present study area but some of the units viz. the Nourpul Formation and the Dhading Dolomite are exposed. Lithology of this area consists of thick to massive-bedded fine to coarse-grained grey stromatolitic dolomite underlain by thin-to medium- 
bedded, greenish grey and purpulish phyllite and slate. Lithological units are described in the following headings. The geological map (Fig.1) and cross section (Fig. 1a) of the study area was prepared at the scale of 1:25,000. The generalized lithostratigraphy of the study area is shown in Fig.2.

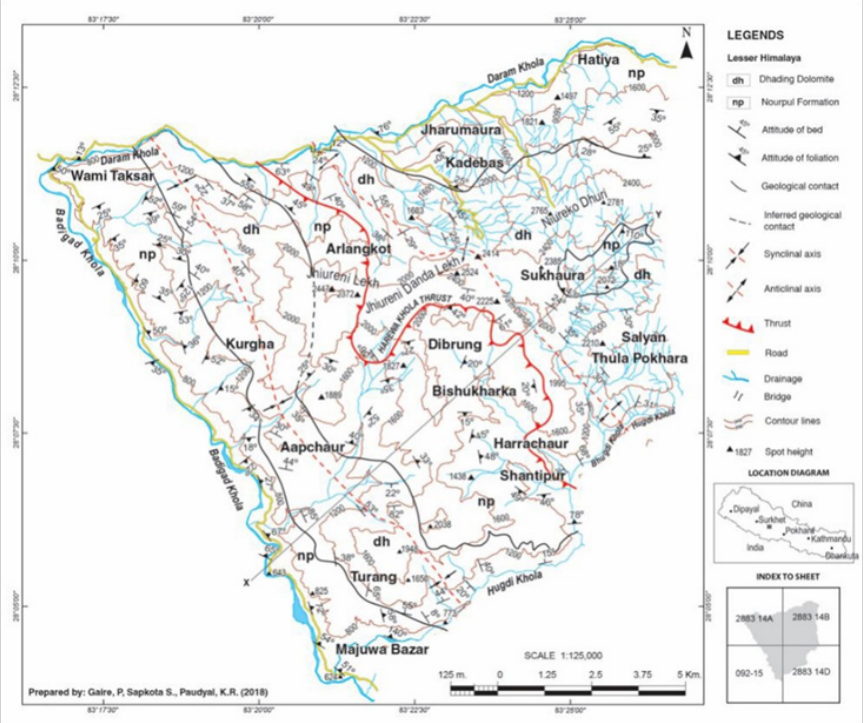

Fig. 1: Geological map of the study area.

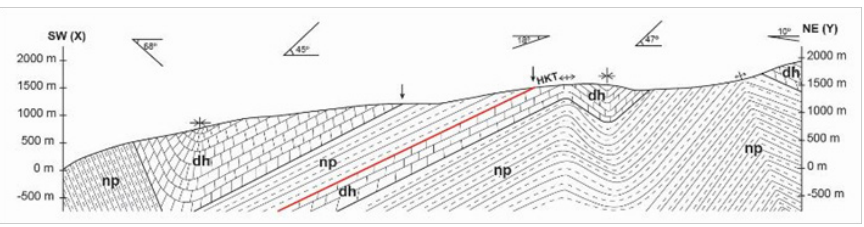

Fig. 1a: Geological cross- section between point X-Y.

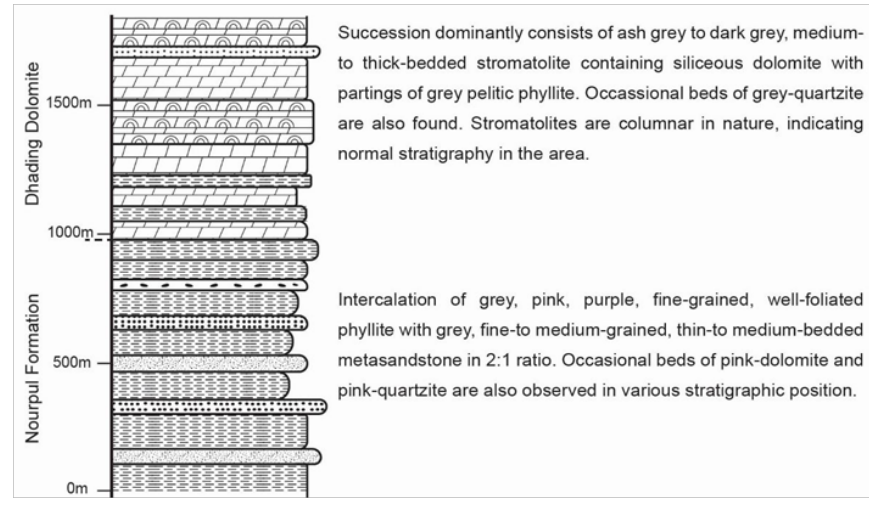

Fig. 2: Columnar section along the Daram Khola, northern limb of Jyam Danda Anticline.

\section{Nourpul Formation}

This formation was named after the village of Nourpul south of Dhading by Stöcklin and Bhattarai (1977). The Nourpul Figure 1a: Geological cross- section between point X-Y. Formation is widely distributed in Majuwa Bazar, Wami Taksar, Shantipur, Harrachaur, Bishukharka, Dibrung area at Gulmi District and
Arlangkot, Kadebas, Hatiya area of Baglung District.Lower part of the succession consists of grey thin-to medium-bedded, fine-to medium-grained, phyllite with laminated phyllite/slate and calcareous phyllite at some places. Middle part consists of thick-bedded, medium-grained, grey, siliceous stromatolite containing dolomites with varying proportion of thick-bedded, medium-to coarse-grained, grey metasandstone and quartzite and medium-bedded, fine-to medium-grained, grey, psammitic phyllite. Upper part consists of green-purple phyllite interbedded with green coloured shale and metasandstone in various proportion.

\section{Dhading Dolomite}

The name Dhading Dolomite was first used by Stöcklin and Bhattarai (1977) from the place Dhading Bensi of central Nepal. The Dhading Dolomite is widely distributed in Turan, Aapchaur, Kurgha area of Gulmi District and is widely distributed in the north east area of Bhugdi Khola, Thale Pokhara, Salyan, Neureko Dhuri, Daha Lekh, Jhureni Lekh area of Baglung District. In the lower part of the unit consists of medium-to thick-bedded white dolomite with imprints of algal mats and stromatolites. Grey coloured psammitic phyllite appears as partings within the dolomites. In the middle part, the thickness of dolomite beds increases and contains abundances of preserve stromatolite, rare parting of phyllite and few intra formational conglomerates are also observed. At the top most part content of dolomite decreases.

\section{River Terraces}

More than $450 \mathrm{~m}$ thick deposits of river terrace are present in the study area. It was deposited by the Badi Gad Khola, Daram Khola and Hugdi Khola.They may occasionally be produced by the incision of bedrock surfaces, but they are most usually the remnants of flood plains which have been trenched by rivers. In the study area, they are found mostly in all the places.

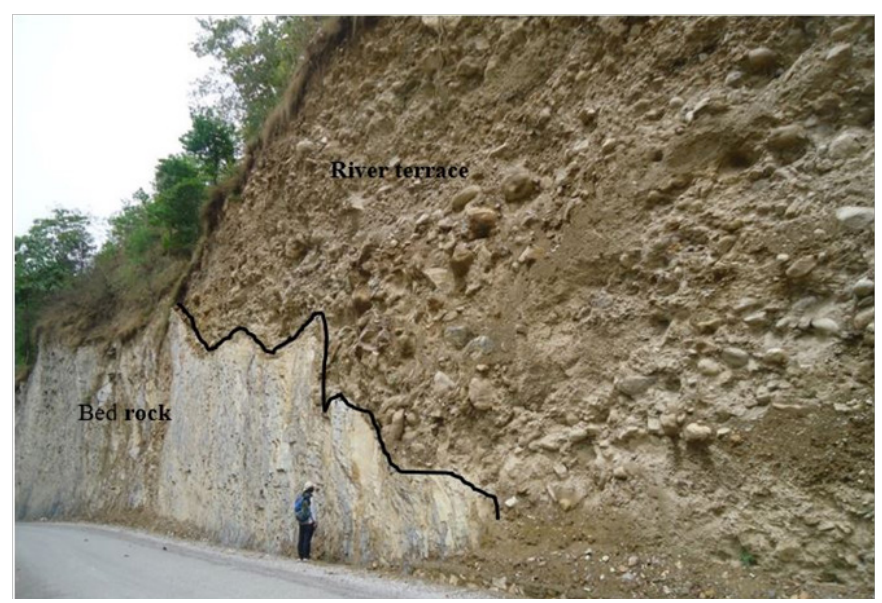

Fig. 3: Outcrop showing the bed rock and river terrace deposit at the Kharbang, Baglung. 
The well exposed river terrace seen at the left bank of Badi Gad River at Kharbang (Fig. 3). The river terrace is extensively eroded and shows up to three terrace benches. The Daram Khola also formed river terrace deposit at the confluence between the Daram Khola and Badi Gad Khola near Kharbang Bazar. In Majuwa Bazar and Wami Taksar, a river terrace deposited is seen in left bank of Badi Gad Khola. River terrace deposits are best seen in the Shantipur area.

\section{GEOLOGICAL STRUCTURES}

Both primary and secondary structures were present in the study area. Primary structures are the structures formed during the deposition period of sediments. The common primary structures are laminations, ripple marks, sun cracks, stromatolites (Fig. 4) etc. Primary structures help to determine the original facing direction of the strata and to determine the condition under which the rock was formed. Structures those formed after the formation of rock or at a time of deformation are called secondary structures. Minor folds, fault, foliation, boudinage are the secondary structures observed in the area.

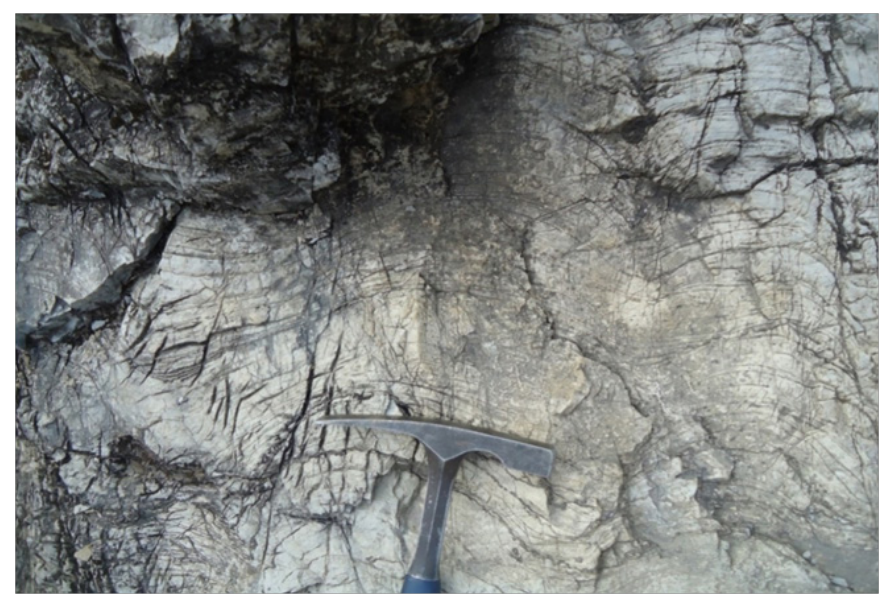

Fig. 4: Outcrop of the Dhading Dolomite observed on the way to Kadebas showing columnar stromatolite indicating normal succession of the Dhading Dolomite.

\section{PETROGRAPHY}

The study area comprises the two lithostratigraphic units. The thin section prepared from the sample collected from the Nourpul Formation and the Dhading Dolomite.The sample(L11) was collected from Hugdi Khola of Shantipur (Fig. 5a). It is a sample of psammitic phyllite. it comprises well developed preferred orientation of minerals. The minerals composition is visually estimated as quartz $30 \%$, feldspar $10 \%$, sericite $35 \%$, unidentified minerals $25 \%$. One set of foliations is present as indicated by the preferred orientation of chlorite.Sample L93, this sample was collected from Bhuwa Sidhi (Fig. 5b). It was sample of metasandstone. Under thin section it comprises more than $90 \%$ of the quartz, preferred orientation of mineral is least developed. Grain boundaries among quartz is found intendent to sutured. Out of many sample are collected from various parts of the study area; few samples were examined under the microscope by preparing thin sections to study grade of metamorphism. The study area comprises only one chlorite grade existence.

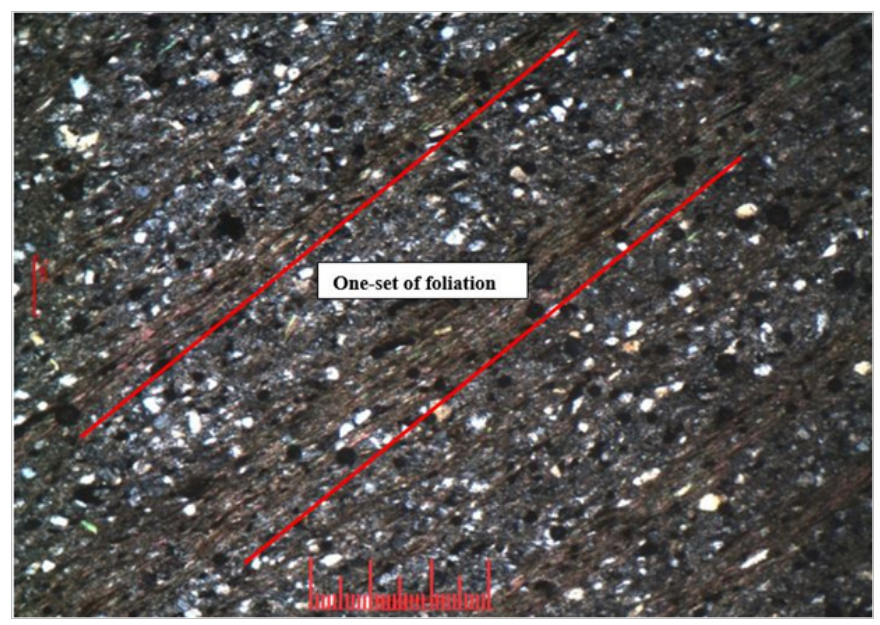

Fig. 5a: Photomicrograph of the psammitic phyllite Nourpul Formation at Hudgi khola, Majuwa Bazar(L11).

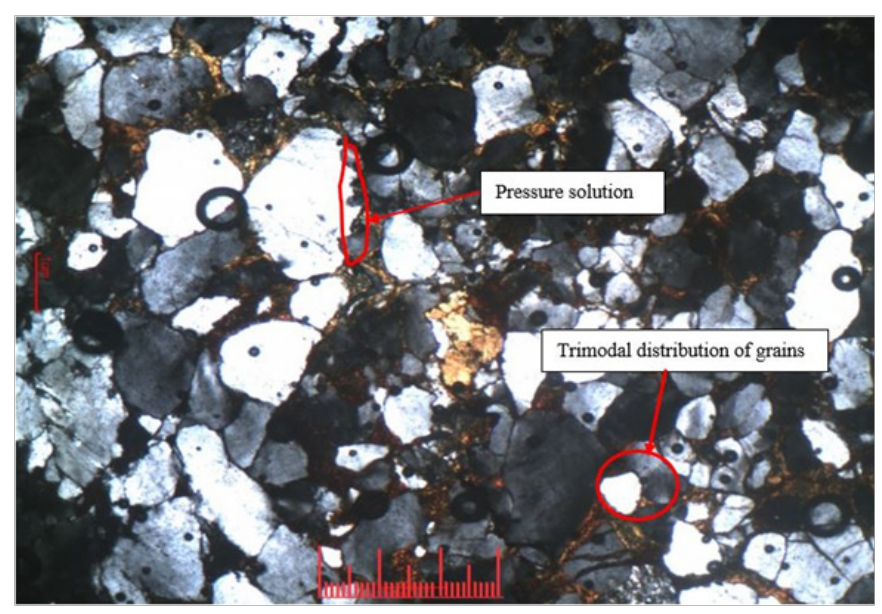

Fig. 5b: Photomicrograph of the metasandstone at Bhuwachiti (L93).

\section{MINERAL RESOURCES}

The present study covers Majuwa Bazar- Shantipur- Wami Taksar area, where several types of minerals are recognized. Metallic and non- metallic minerals resources are observed in different parts of the study area. Metallic mineral copper (i.e. malachite) and iron (i.e. hematite) is found in Bhirkhani area. The non- metallic deposits of roofing quality slates are observed in the way from Bhanjyan to Oliban. The dolomite resources are also observed in many areas in northeast part of Badi Gad Khola at Pipal pata, Turang, Sukhaura and Thulo Pokhara area. In this area some significant deposits of located construction materials are deposited, and local mining is carried out in these days. 


\section{DISCUSSION}

Present study was carried out to know the geology and mineral resources of the Shantipur-Wami Taksar area. The geological map of the study area was prepared at 1:25,000 scale. The area consists of the Nourpul Formation with grey, fine-grained pelitic and psammitic phyllite with grey, light-green, fine- to mediumgrained, medium-bedded metasandstone beds in Majuwa Bazar-Wami Taksar road section area. Dhading Dolomite with grey, thick-bedded stromatolite containing siliceous dolomite with parting of grey fine-grained, phyllite and minor amount of quartzite. The study area with the most accepted work of Stöcklin and Bhattarai (1977); Stöcklin (1980) in central Nepal Lesser Himalaya with which the present study area is targeted to be correable with the rocks of the Nawakot Group in Central Nepal. However, there is no Purebensi Quartzite at the basal part of the Nourpul Formation.Geological investigation of Sakai (1985) terminates his map at Ridi Bazar to the west. However, the geological units of the Kali Gandaki Super Group are not found extended towards the present study. Instead, the rocks of the region are correable with the rocks of the Nawakot Group in Central Nepal. Paudyal(2014) which shows the upper part of the Nourpul Formation has been divided into members like the Labdi Khola Member and the Bandipur Slate. The Nourpul Formation of the present study can be compared with these two members of Paudyal (2014). However, the slate unit is not mappable in the area. The Dhading Dolomite is almost perfectly correlated in these works.

\section{CONCLUSION}

In the present study two lithostratigraphic units of the Nawakot Group were identified. The geological map and cross section were prepared at a scale of 1:25,000. Lithostratigraphic sequence of the area shows different type of lithology compared to that of west central Nepal.The geology of the study area consists of the rock of the Nawakot Group. The mappable lithological units are the Nourpul Formation and the Dhading Dolomite. One metamorphism zone i.e., chlorite zone in an area have identified from the petrological study.Malachite an ore of copper is found as occurrences in the Bhirkhani area. It is found in the form of boudinages and vein-type. Most probably it is hydrothermal in nature. Similarly, hematite an ore of iron is found as occurrence in phyllites and metasandstone of the Nourpul Formation. Since the deposit is parallel and intercalated to host rocks indicating syngenetic in nature.Slate is found in the Nourpul Formation at the Bhanjyan area. The deposit of slate is sub-economic. In this area slate mainly used for the roofing.Dolomite is found in the Dhading Dolomite at different locations such as Turang, Kadebas, Thale Pokhara and Malarani area. Huge amount of dolomite deposit in this area. Construction materials are deposits at the river terrace. Large amount of sand and gravel deposits at the Wami Taksar area.

\section{ACKNOWLEDGMENTS}

My deep and cordial gratitude goes to the Central Department of Geology (CDG, TU) for providing the laboratory facilities in the department.

I offer my earnest thanks to my friend Mr. Sashi Tamang and Sandeep Thapa for the perpetual help in the preparation of polished section. We express sincere gratitude to the staff of Central Department of Geology (CDG) for their help and support.

\section{REFERENCES}

Dhital, M.R., Thapa, P.B., and Ando, H., 2002. Geology of the inner Lesser Himalaya between Kusma and Syangja in western Nepal. Bulletin of the Department of Geology, v. 9, Special Issue, pp. 1-60.

DMG (Department of Mines and Geology), 2000. Geological map of west Gulmi, Syangja and Palpa Districts in 1: 50,000 scale. Published by the DMG.

Paudyal, K. R., 2014. Geological and Petrological Evolution of the Lesser Himalaya between Muling and Damauli, Central Nepal. A Dissertation for the Award of Doctor of Philosopy(Ph. D.) Degree in Geology submitted to the Central Department of Geology, Institute of Science and Technology, Tribhuvan University, Nepal., 252p.

Sakai, H., 1985, Geology of the Kali Gandaki Supergroup of the Lesser Himalaya in Nepal. Memoirs of Facility of Science, Kyushu University, Ser. D. (Geology, V. 25 93), pp. 337-397.

Stöcklin, J., 1980. Geology of Nepal and its regional frame: Thirty-third William Smith Lecture. Journal of the Geological Society of London, v. 137(1), pp. 1-34.

Stöcklin, J, and Bhattarai, K.D., 1977. In: Himalaya Report Geology of Kathmandu Area and Central Mahabharat Range Nepal. Department of Mines and Geology Kathmandu, Nepal, $86 \mathrm{pp}$. 